\title{
Enteral Route of Administration
}

National Cancer Institute

\section{Source}

National Cancer Institute. Enteral Route of Administration. NCI Thesaurus. Code C38209.

Administration of a substance by the way of the gastrointestinal tract, usually for

systemic action. Drug bioavailability can be affected due to enzymatic degradation by

intestinal tissues and microbes, and first-pass hepatic metabolism. 